\title{
The Effect of Polysaccharides Peptides Ganoderma lucidum to Aortic Foam Cell Count and Lipid Profile in Type 2 Diabetic Model Rattus norvegicus Strain Wistar
}

\author{
Djanggan Sargowo ${ }^{1, *}$, Titin Andri Wihastuti ${ }^{2}$, Cathrine Theodora Sukotjo $^{3}$, Prasanti Mahesa Anjani ${ }^{3}$, \\ Olivia Handayani ${ }^{1}$, Liemena Harold Adrian ${ }^{1}$
}

\begin{abstract}
${ }^{1}$ Department of Cardiology and Vascular Medicine, Faculty of Medicine, Brawijaya University, Jl. Veteran, Ketawanggede, Malang, Indonesia ${ }^{2}$ Department of Biomedical Science, Faculty of Medicine, Brawijaya University, Jl. Veteran, Ketawanggede, Malang, Indonesia ${ }^{3}$ Faculty of Medicine, Brawijaya University, Jl. Veteran, Ketawanggede, Malang, Indonesia
\end{abstract}

*Corresponding author. E-mail: djanggan@yahoo.com

Received date: Jan 3, 2017; Revised date: May 1, 2017; Accepted date: May 15, 2017

\section{Abstract}

$\mathrm{B}$ ACKGROUND: Type 2 Diabetes Mellitus (DM) is one of dominant factors in cardiovascular deaths and induces endothelial dysfunction. A definite sign of endothelial dysfunction is foam cells formation derived from oxidized LDL. This study was conducted to determine the effect of Polysaccharides Peptides (PsP) Ganoderma lucidum to foam cell counts and lipid profile in diabetic model rats with high-fat diet.

METHODS: Treatment group was categorized to negative control, positive control, DM-50, DM-150, and DM-300. Type $2 \mathrm{DM}$ induced by Streptozotocin. PsP was administered with predetermined doses on each treatment's group (50, 150 and $300 \mathrm{mg} / \mathrm{kgBW}$ ) for 12 weeks. Measurements of foam cell count were held after obtaining rat's aorta. To assess lipid profile, blood sample was taken from the rat's heart. The data were analyzed by One-way ANOVA and Post Hoc Tukey tests.
RESULTS: The administration of Ganoderma lucidum PsP to diabetic model rats provided a significant difference in lowering foam cell ( $p=0.017$; CI 95\%). It also gave significant difference between levels of each lipid components (Total Cholesterol, Trygliceride, LDL and HDL) in at least two treatment groups ( $p=0.010$; CI 95\%). Based on Post Hoc Tukey tests, the relationship between administration of PsP and foam cell is significant $(p=0.002)$.

CONCLUSION: PsP has antioxidant and anti-inflammatory effect in type 2 DM model Rattus norvegicus strain Wistar, which can inhibit atherosclerosis and endothelial damage process. Further studies are necessary to evaluate the benefits of PsP as an adjuvant therapy in the management of diabetic dyslipidemia.

KEYWORDS: PsP, Ganoderma lucidum, foam cell, lipid profile, DM

Indones Biomed J. 2017; 9(3): 153-9

\section{Introduction}

By 2013, a total of 382 million people in the world suffer from diabetes mellitus (DM). In the year 2035, this figure will be increased to 592 million. Indonesia is included in 10 countries in the world with the largest number of diabetics, with the number of patients as much as 8.5 million by 2013 ( $7^{\text {th }}$ rank) and is expected to be increased to 14.1 million of patients by 2035 ( $6^{\text {th }}$ rank).(1) Atherosclerosis is 2-6 times more likely in type 1 and type 2 DM than nondiabetic patients.(2) Cardiovascular disease is the leading complication caused death and disability in patients with diabetes.(1) Major cardiovascular event is the global number one cause of death. It is estimated about 17.3 million people were died from cardiovascular diseases in 2008, representing $30 \%$ of all deaths globally.(3) This is primarily caused by atherosclerosis, i.e., the plaque accumulates 
in the arteries that are supposed to bring oxygen-rich blood to the entire body.(4) The formation of plaque and endothelial damage begins first with the formation of foam cell originating from the macrophage phagocytosis which acts against the accumulation of lipid in endothelial cells so that it can act as an indicator of the occurrence of vascular damage due to DM.(5)

Patients with DM have a number of factors that increase atherosclerosis risk. Change in plasma lipid levels associated with diabetes is one of the key factors.(6) Dyslipidemia, which affects nearly $50 \%$ of patients with type $2 \mathrm{DM}$, is one of the cardiovascular risk factors, characterized by increased levels of triglycerides, low high density lipoprotein (HDL) levels, and the number of particles of small dense low density lipoprotein (LDL). (7) The control of dyslipidemia is needed to prevent the risk of complications of DM. One of routine examination that can be done to detect the presence of dyslipidemia is by obtaining lipid profile test. The adenosin tryphosphat (ATP) III guidelines recommend that every individual is expected to perform screening with lipid profile test begins from the age of 21 years old, once every 5 years and in shorter intervals if they have a certain disease or risk factor.(8)

In diabetic patients, oxidative stress increases and can accelerate the development of complications through the metabolism of glucose and free fatty acid accumulation on the state of diabetes and insulin resistance.(9) The condition of oxidative stress is increased in DM patients, requiring sources of antioxidants in order to compensate. One of the sources of antioxidants are obtained in the polysaccharides peptide ( $\mathrm{PsP}$ ). $\mathrm{PsP}$ is one of the compounds which can be obtained from the extract of Ganoderma lucidum fungus.(10)

Some studies mention that the extract of Ganoderma lucidum PsP has an effect as anti-hyperglycemia, antiinflammatory and anti-tumor. Ganoderma lucidum PsP containing the antioxidative enzymes and are capable of suppressing reactive oxygen species (ROS) so that it becomes more stable. Antioxidant effects of Ganoderma lucidum PsP can be used to prevent and treat atherosclerosis and type 2 DM. $(10,11)$

\section{Methods}

This research used 35 Wistar rats (Rattus norvegicus) in a central laboratory of life sciences Bioscience University of
Brawijaya for 1 week. The whole rats were given standard feed in order to adapt the rats with its environment. The feed was given once in 24 hours, which later replaced by the next day. Each feed was weighed 30 grams. After a period of acclimatization of rats, it continued with the process of randomization of the rats to be grouped into each treatment's group.

The treatment in each group was begun by categorizing the rats to negative control group, positive control group, DM-50 group, DM-150 group, and DM-300 group. The given feed on each group treatment was a high-fat diet (HFD) or atherogenic diet that was made with the composition of chicken feed (ParS 57.3\% and flour 31.8\%) and added with $1.9 \%$ cholesterol, $0.1 \%$ cholic acid and $8.9 \%$ pork oil. HFD was given every day with a 24-hours gap with the weight of each feed 40 grams over the past 4 weeks. Then the rats were induced with Streptozotocin (STZ) $30 \mathrm{mg} / \mathrm{kgBW}$ so that it could be categorized as a type $2 \mathrm{DM}$. Blood glucose tests were also carried out in rats after administration of STZ to determine whether random blood sugar levels of the rat was already included in type $2 \mathrm{DM}$ criteria or not. After that, the PsP was given in conjunction with the HFD for 4 weeks and ended with surgery. HFD was administered with a total allotment of time i.e., 12 weeks to ensure the occurrence of endothelial dysfunction that may be observed with the histopathology specimen in diabetic model rats.

PsP was administered with predetermined doses on each treatment's group $(50 \mathrm{mg} / \mathrm{kgBW}, 150 \mathrm{mg} / \mathrm{kgBW}$ and $300 \mathrm{mg} / \mathrm{kgBW}$ ). Determination of Ganoderma lucidum PsP doses of 50,150 , and $300 \mathrm{mg} / \mathrm{kgBW}$ was done based on previous studies regarding the effect of Ganoderma lucidum administration to diabetic model rats. $(11,12)$

The measurement of foam cell count was held after the surgery of the rats, and obtaining the aorta of the rats in order to assess the foam cell count. Tissue fixation was done by using paraffin block method which was then mounted on the glass objects (slides) for observing the foam cells. Aortic preparations using to observe the foam cell were stained with Hematoxylin-Eosin. After that, the foam cell was read by using light microscope with a magnification of 400x and used software Dot Slide Olyvia with field of view 10 times for each aortic preparation.(13)

To assess lipid profile, the preparation was begun with surgery. A blood sample was taken from the rat's heart followed by separation of blood serum from blood cells. Lipid profile measurement was done by using analyzer machine, the Cobas Mira. Data analysis was done by using One-way ANOVA and Post Hoc Tukey tests. 


\section{Results}

\section{The Effect of PsP on Foam Cell Count}

The administration of PsP decreased foam cell count observed in the aortic tissue of diabetic model rats, which was observed through aortic tissue of diabetic model rats. Compared to positive and negative control groups, the diabetic model rats group which were given certain dose of PsP showed decrease of mean foam cell count. In positive control group (DM), the mean of foam cell count was obtained as the highest level among all treatment groups, i.e., about $4.375 \pm 1.797$ cells per 10 field of view. The highfat diet group with PsP dose $150 \mathrm{mg} / \mathrm{kgBW}$ showed foam cell count about $1.875 \pm 0.854$ cells per 10 field of view, more less compared to DM+PsP 50 group which showed foam cell count as $3.167 \pm 1.607$ cells per 10 field of view. $\mathrm{DM}+\mathrm{PsP}$ 300 group showed the least foam cell count compared to all treatment groups, i.e., as many as $1.750 \pm 0.957$ cells per 10 field of view (Figure 1).

The administration of Ganoderma lucidum PsP provided a significant difference in lowering the number of foam cell ( $p=0.017$ ) because the value of $\mathrm{p}$ for foam cells was smaller than 0.05. The Post Hoc Test with Tukey HSD method showed that the results of the significance of a decrease in the foam cell count with a specific dose of PsP Ganoderma lucidum with doses of 50, 150 and $300 \mathrm{mg} / \mathrm{kgBW}$ in Wistar rats (Rattus norvegicus) were different within each group. There was a significant difference between the negative control group, $\mathrm{DM}+\mathrm{PsP} 300, \mathrm{DM}+\mathrm{PsP} 150$, and $\mathrm{MD}+\mathrm{PsP} 50$ compared to the positive control group (Figure 2). It can be assumed that the administration of PsP may cause a significant difference in foam cell counts as compared to the positive control group. The administration of PsP gave no significant difference compared to negative control group. The relationship between the administration of the PsP and foam cell was significant ( $p=0.002 ; \mathrm{r}=-0.731$ ).

The correlation between the groups that received the HFD and Ganoderma lucidum PsP dose showed a decrease in the number of foam cell approaching the amount of the foam cell count in standard diet group. DM+PsP150 group and $\mathrm{DM}+\mathrm{Ps} 300$ group were the groups that demonstrate the non-significant $p$ value (approaching 1.00) and very powerful $r(0.993$ and 1.000) as compared to negative control group. This showed that the effects of the administration of Ganoderma lucidum PsP had already occurred on the dose of $150 \mathrm{mg} / \mathrm{kgBW}$ which proved by the $p$ value that was not significant and the $r$ value that was very powerful. The

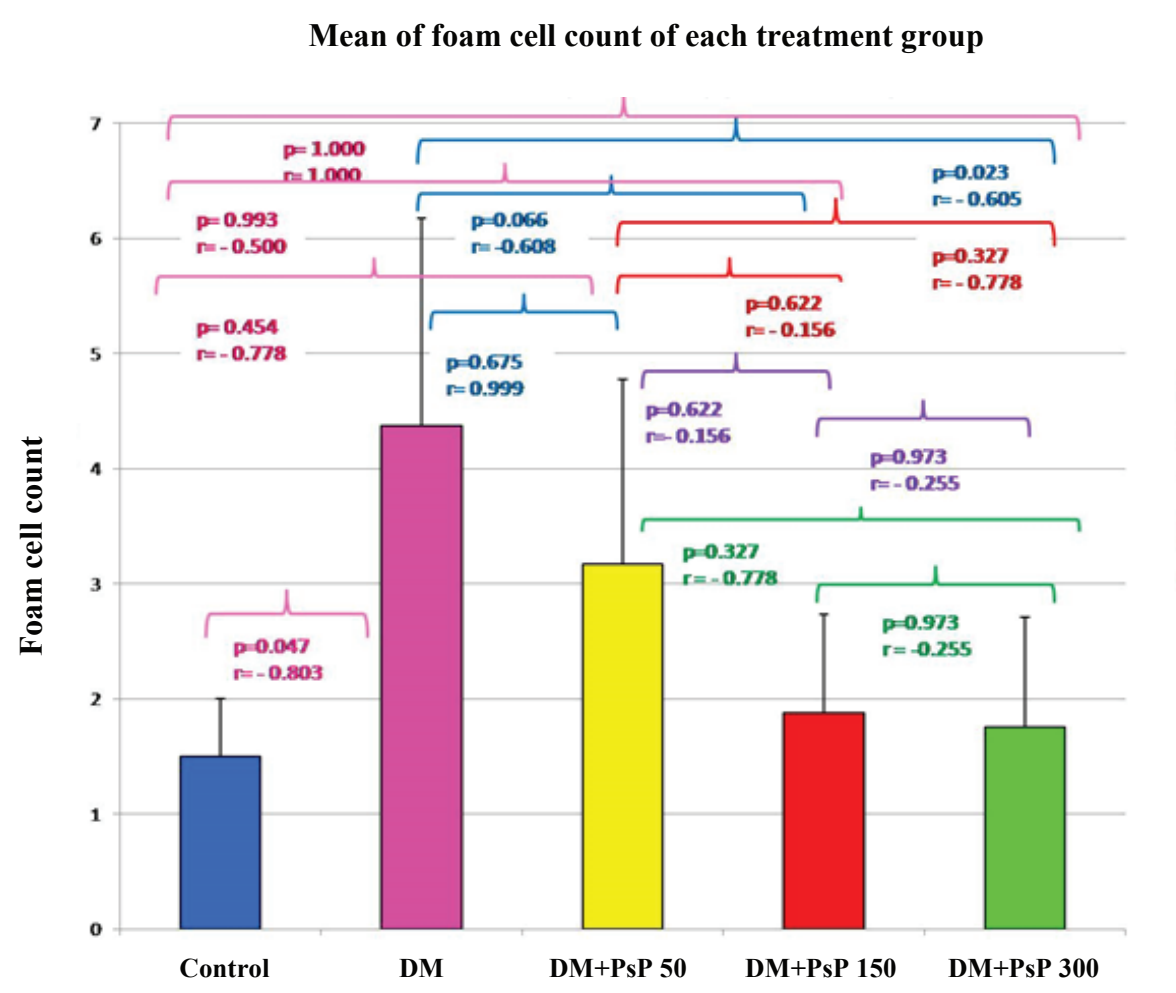

Treatment groups

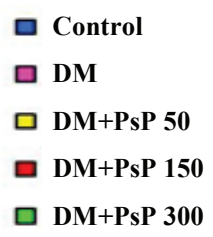

Figure 1. Mean of foam cell count of each treatment group. 


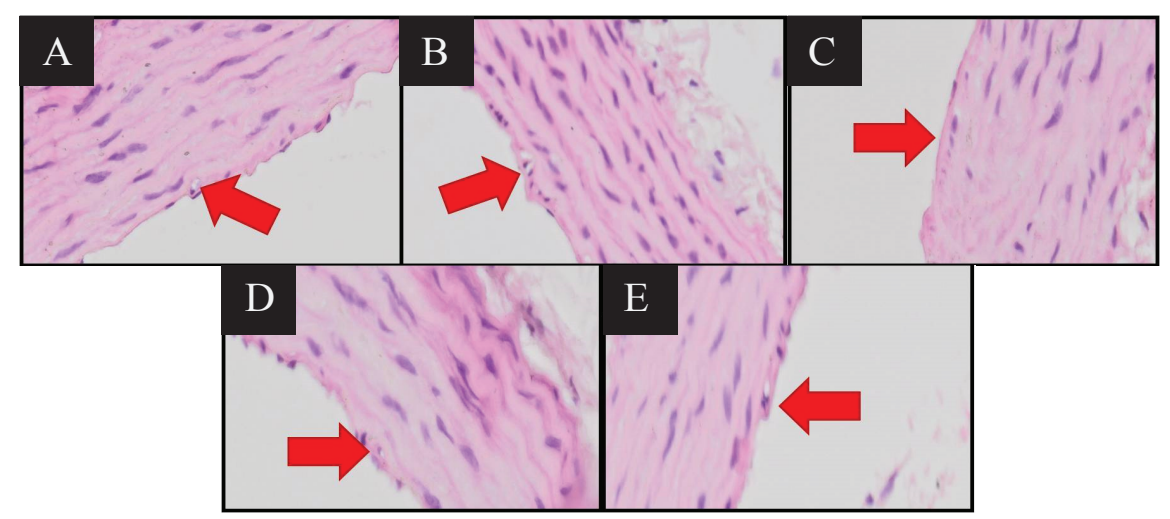

Figure 2. Foam cell in negative control group (A), positive control group (B), DM+PsP 50 group (C), DM+PsP 150 group (D) and DM+PsP 300 group (E).

conclusion that can be drawn was a dose of $150 \mathrm{mg} / \mathrm{kgBW}$ of Ganoderma lucidum PsP was an adequate dose for acting as an external antioxidant in type $2 \mathrm{DM}$, compared to the dose of $300 \mathrm{mg} / \mathrm{kgBW}$. Another consideration which led to an adequate dose of PsP $150 \mathrm{mg} / \mathrm{kgBW}$ was a dose of 150 $\mathrm{mg} / \mathrm{kgBW}$ PsP more easily consumed as well as the fewer side effects and lower manufacturing price.

Compared to the group received the highest dose of PsP, i.e., $300 \mathrm{mg} / \mathrm{kgBW}$ PsP, the foam cell count of the negative control group remained less than a group of DM-PsP 300 group. This is because a group of PsP 300 is receiving HFD that was not given to negative control group, instead.

\section{The Effect PsP on Lipid Profile}

Total cholesterol levels measurement results showed that the lowest mean level was obtained in the negative control group (47.20 mg/dL) and the highest mean level was in the positive control group (130.65 $\mathrm{mg} / \mathrm{dL})$. The diabetic group with PsP 50 had an average of $115.75 \mathrm{mg} / \mathrm{dL}$, diabetic group with PsP 150 of $103.05 \mathrm{mg} / \mathrm{dL}$ and diabetic group with PsP 300 of $89.50 \mathrm{mg} / \mathrm{dL}$ (Figure $3 \mathrm{~A}$ ).

The results of the measurement of triglyceride levels showed that the lowest average was obtained in the negative control group (76.20 mg/dL) and the highest mean level was in the positive control group $(661.60 \mathrm{mg} / \mathrm{dL})$. The diabetic group with PsP 50 had an average of $537.60 \mathrm{mg} / \mathrm{dL}$, diabetic group with PsP 150 of $347.80 \mathrm{mg} / \mathrm{dl}$ and diabetic group with PsP 300 of $274.80 \mathrm{mg} / \mathrm{dL}$ (Figure 3B).

Figure $3 \mathrm{C}$ showed the result of the measurement of LDL levels. The calculation of the lowest mean level was obtained in the negative control group $(13.16 \mathrm{mg} / \mathrm{dL})$ and the highest mean level was in the positive control group (41.08 $\mathrm{mg} / \mathrm{dL})$. The diabetic group with PsP 50 had an average of $25.30 \mathrm{mg} / \mathrm{dL}$, diabetic group with PsP 150 of
$24.56 \mathrm{mg} / \mathrm{dL}$ and diabetic group with PsP 300 of $24.58 \mathrm{mg} /$ dL. A decrease in LDL cholesterol levels seems in line with the increased dose of PsP.

The results of measurements of the levels of HDL (Figure 3D) showed that the lowest mean level was obtained in the positive control group $(22.92 \mathrm{mg} / \mathrm{dL})$ and the highest mean level in the negative control group $(33.30 \mathrm{mg} / \mathrm{dL})$. The diabetic group with PsP 50 had an average of 24.63 $\mathrm{mg} / \mathrm{dL}$, diabetic group with PsP 150 of $30.54 \mathrm{mg} / \mathrm{dL}$ and diabetic group with PsP 300 of $31.08 \mathrm{mg} / \mathrm{dL}$.

Using One-way ANOVA test with 95\% confidence interval, there was a significant difference between the levels of each lipid components in at least two treatment groups $(p=0.010)$. Total cholesterol levels in positive control group were significantly different compared to diabetic group with PsP 300. This showed that the dose of $300 \mathrm{mg} / \mathrm{kgBW}$ could significantly lower total cholesterol levels in diabetic model rats. In addition, administration of PsP $300 \mathrm{mg} / \mathrm{kgBW}$ could also lower the level of triglycerides $(p=0.001)$. Administered a dose of $150 \mathrm{mg} / \mathrm{kgBW}$ PsP could lower the level of LDL cholesterol ( $p=0.010)$ significantly, but gave no significant differences in the levels of HDL cholesterol $(p=0.232)$.

\section{Discussion}

The administration of a diet high in cholesterol and saturated fat continuously led to disruption of either lipid or carbohydrate metabolism. Impaired fat metabolism will cause an increase in LDL and decrease in HDL that will become the source of dyslipidemia and eventually fall on the condition of type $2 \mathrm{DM}$ in which occurs the process of atherosclerosis with chronic inflammation that causes the development of endothelial dysfunction.(14) HFD which is given to the rats in positive control group (DM) is a 

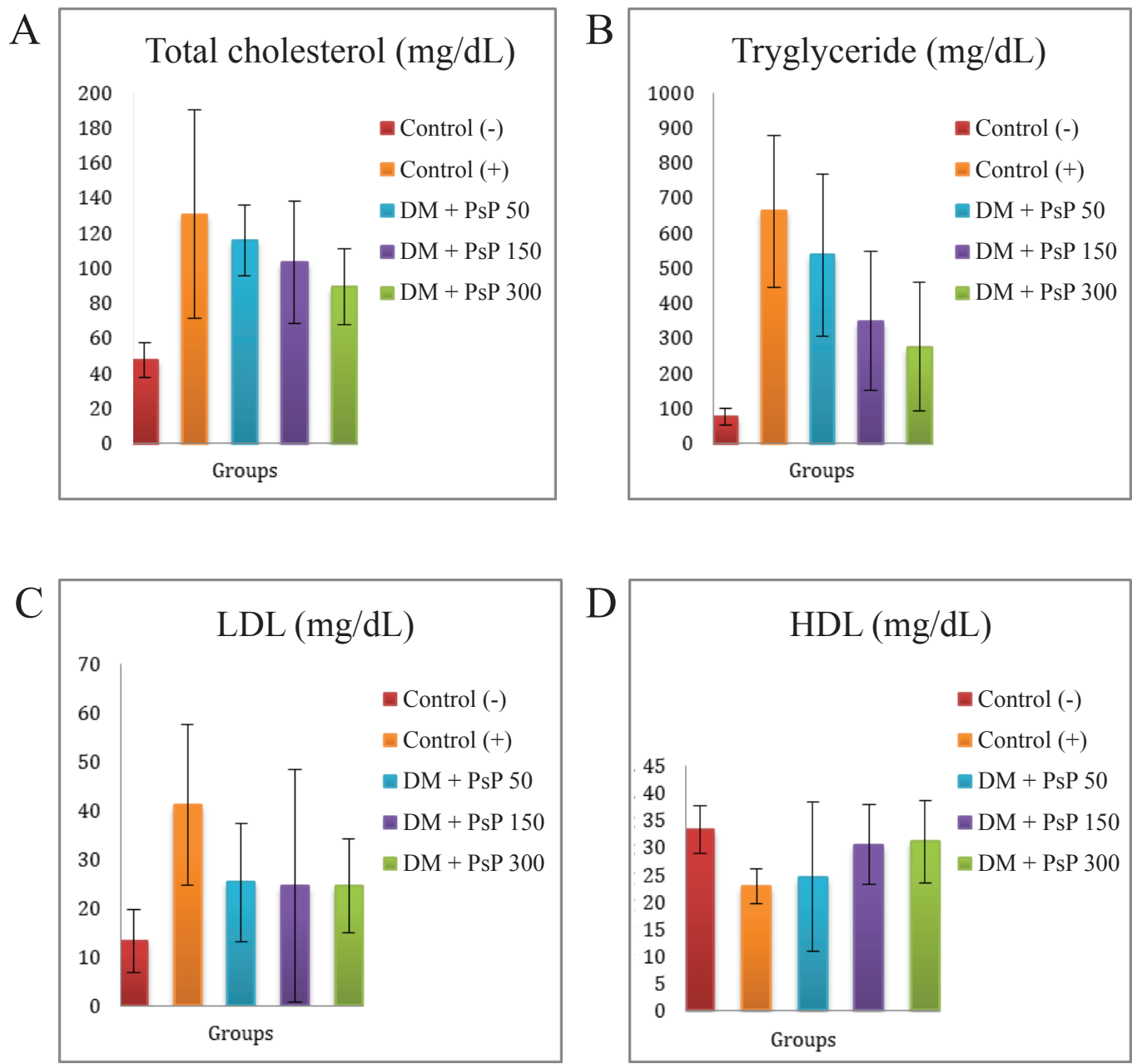

Figure 3. Graphic of mean level of lipid profile in each treatment group: total cholesterol level (A), triglyceride (B), LDL cholesterol (C) and HDL cholesterol (D).

feed containing high concentration of unsaturated fats or polyunsaturated fatty acids (PUFA) so is very potential in increasing the level of oxidative stress in the animal body. PUFAs are the type of fat that is susceptible to a variety of oxidative processes that occur in the body. One of the most influential forms of free radicals that cause an increase in oxidative stress in type $2 \mathrm{DM}$ condition is hydrogen peroxide $\left(\mathrm{H}_{2} \mathrm{O}_{2}\right)$. Lipid peroxidation, i.e., damage of PUFA because of the activity of free radicals in changing the fatty chain form of PUFA, also caused by $\mathrm{H}_{2} \mathrm{O}_{2}$ and induce cell damage which is characterized by damage of the cell membrane, enzyme inactivation, and the production of secondary toxic products which harm the cells.(15)

In this study, there are not significantly different results between the negative control group and the HFD group that received Ganoderma lucidum PsP at largest dose, i.e., 300 $\mathrm{mg} / \mathrm{kgBW}$. The HFD group with $300 \mathrm{mg} / \mathrm{kgBW}$ PsP has foam cell number differed more or less one cell compared to the mean amount of foam cell in the negative control group.
This can occur because of Ganoderma lucidum PsP have properties as an external antioxidant on the conditions of type 2 DM. In the former study, Ganoderma lucidum has been obtained useful in lowering plasma blood glucose, PEPCK gene expression, and body weight of rat as the subject (the reduction of body fat, particularly abdominal fat) as a benefit of the PsP as a therapy against DM type 2. In addition, Ganoderma lucidum PsP also has potential as an external antioxidant agent. It could acts as scavenger against free-radical molecules so that it bound to antioxidants and unable to react with increased concentration of PUFA particularly on the condition of type 2 DM.(12) Reduction of fat deposition is causing depletion of PUFA which is vulnerable to oxidative process by free radicals so the reaction of lipid peroxidation does not occur and vascular damage can be avoided.

The antioxidant effects of Ganoderma lucidum PsP can be observed from the pattern of decline in the number of foam cell in each treatment group that received the 
HFD-PsP as compared to the mean amount of foam cell in positive control group. This is due to the presence of antihyperglycemia effects of Ganoderma lucidum $\mathrm{PsP}$ which led to a change of the composition of LDL cholesterol and HDL as well as deposition of body fat and weight loss in animals that received HFD and also PsP. Ganoderma lucidum PsP has the ability to cause a decrease in serum insulin levels, fasting blood glucose (GDP), and LDL cholesterol as well as improving HDL cholesterol in the rats who experience type 2 DM through the injection of STZ.(11) The decrease in fat deposition in the administration of Ganoderma lucidum PsP shows its ability as a free radical scavenger against increased oxidative stress conditions in type 2 DM. Ganoderma lucidum PsP is unable to hinder the process of the lipid peroxidation in rats (Rattus norvegicus) strain Wistar which received the HFD continuously, so that inhibit the onset of lipid metabolism disorders that further cause the oxidation of LDL cholesterol to be Ox-LDL form. OxLDL levels which are reduced in the body will prevent the formation of foam cell through the reduction of activation of various pro-inflammatory cytokines, including necrosis factor kappa-B (NF- $\mathrm{B})$ activation so that endothelial dysfunction can be reduced.(16)

Some previous external research has proved the potential of Ganoderma lucidum PsP as anti-inflammatory agents and antioxidants. According to the Song, et al., Ganoderma lucidum PsP has the ability to stimulate the body's immune response and have the effect of anti-angiogenesis and anti-tumor if given in pathologic conditions.(17) Research by Chen, et al., and Jia, et al., also support the statement that Ganoderma lucidum PsP lipid peroxidation and blood glucose levels in diabetic model rats. $(10,18)$ Other studies by Menget, et al., states that Ganoderma lucidum PsP has the potential in the treatment of myocardial fibrosis with lower accumulation of collagen levels through the decrease of total hydroxyproline on the myocardium of the ventricles of the rat heart.(19) In addition, it also obtained that the medium dose of Ganoderma lucidum PsP in animals with type $2 \mathrm{DM}$ causes a decrease of glycosylation end product or the increased level of advanced glycosylation end products (AGE) in the condition of hyperglycemia and to prevent the process of myocardial fibrosis. Blood glucose and $\mathrm{HbA} 1 \mathrm{c}$ levels in rats that received doses of Ganoderma lucidum PsP are also showing a significant decrease as a result of the administration of Ganoderma lucidum PsP. The results of such research in line with the hypothesis concerning the effects of Ganoderma lucidum PsP as antioxidants in this research and undertaking to strengthen the fact that Ganoderma lucidum PsP can be included in the process of atherosclerosis preventive efforts in type 2 DM condition.(19)

The effectiveness of PsP as an external antioxidant can be obtained by comparing the antioxidant abilities of Ganoderma lucidum PsP with another antioxidant agent. In comparison with ascorbic acid (Vitamin C), Ganoderma lucidum PsP is still 100 times less potent.(12) A study carried out by Fikriah about turmeric or curcumin's potential as antioxidants in inhibiting the development of atherosclerosis process claimed that turmeric was able to reduce the amount of foam cells with the ability which is almost similar to Ganoderma lucidum PsP.(20) The smaller mean amount of foam cells in turmeric extracts administration compared to the mean amount of foam cells that arise after the administration of Ganoderma lucidum PsP can occur due to the administration of HFD or atherogenic diet provided in conjunction with the administration of turmeric extracts in a bit shorter time (10 weeks) compared with the administration of HFD in conjunction with Ganoderma lucidum PsP (12 weeks). Another benefit of the antiinflammatory effect of Ganoderma lucidum PsP has been attempted to be researched earlier. Ganoderma lucidum PsP has the ability to decrease the inflammatory process in type 2 DM by inhibiting atherosclerosis process that occurs in rats which being induced with STZ to stimulate type 2 DM. Other studies by Sliva also support the potential of Ganoderma lucidum as anti-inflammatory agents found that Ganoderma lucidum PsP actively inhibit the transcription factor NF- $\mathrm{NB}$ and activator protein-1 (AP-1) activation which inhibits the expression of urokinase type plasminogen activator-(uPA) and its receptor, uPAR.(21) The adhesion and migration of cells that play a role in the onset of breast and prostate cancer which are invasive also successfully repressed by Ganoderma lucidum PsP who supported the conclusion that Ganoderma lucidum PsP can actively inhibit various inflammatory processes that occur in various pathological conditions experienced by the body.

Improvement of total cholesterol, triglycerides, and LDL cholesterol level in the groups that received PsP therapy are likely due to the action of PsP in regulating DM so that diabetic model rats is no longer experiencing further progress towards complications. Complications of DM in this study are emphasized in cardiovascular disease that is often caused by the presence of atherosclerosis. An early sign of the onset of complications of atherosclerosis in DM patient is the existence of dyslipidemia. Lipid profile improvement means the presence of dyslipidemia is reduced, so it can be said that the PsP can prevent cardiovascular complications of DM. 


\section{Conclusion}

Based on this study, the PsP can be used as adjuvant therapy in the management of type $2 \mathrm{DM}$, i.e., as an antioxidant and anti-inflammatory which can inhibit and slow down the process of atherosclerosis and endothelial damage, to eventually be able to prevent the development of cardiovascular complications. The administration of PsP can reduce the amount of foam cell and improve the lipid profile in diabetic model rats which are fed a diet high in fat. Utilization of fungus Ganoderma lucidum as a product that can be given easily in people with type $2 \mathrm{DM}$ in order to bring benefit to primary and secondary prevention in tyoe 2 DM. Further research is required to find out the effectiveness and safety of Ganoderma lucidum PsP, both in products that can be consumed (food and beverages) as well as drugs.

\section{References}

1. International Diabetes Federation. IDF Diabetes Atlas 6th edition Year: 2013. Brussels: International Diabetes Federation; 2013.

2. Hamamdzic D, Wilensky RL. Porcine models of accelerated coronary atherosclerosis: role of diabetes mellitus and hypercholesterolemia. J Diabetes Res. 2013; 2013: 761415. doi: 10.1155/2013/761415.

3. WHO [Internet]. Cardiovascular Diseases 2011 (cited 2013 Nov 15). Avaliable from: http://www.who.int/mediacentre/factsheets/fs317/ en/.

4. NHLBI [Internet]. Bethesda: National Institutes of Health, Department of Health and Human Services. What Is Atherosclerosis? (cited 2013 Nov 15). Avaliable from: http://www.nhlbi.nih.gov/health/ health-topics/topics/atherosclerosis/.

5. Kushiyama A, Okubo H, Sakoda H, Kikuchi T, Fujishiro M, Sato H, et al. Xanthine oxidoreductase is involved in macrophage foam cell formation and atherosclerosis development. Arterioscler Thromb Vasc Biol. 2012; 32: 291-8.

6. Mooradian AD. Dyslipidemia in type 2 diabetes mellitus. Nat Clin Pract Endocrinol Metab. 2009; 5: 150-9.

7. Vijayaraghavan K. Treatment of dyslipidemia in patients with type 2 diabetes. Lipids Health Dis. 2010; 9: 144. doi: 10.1186/1476-511X9-144.

8. National Cholesterol Education Program (NCEP) Expert Panel on Detection, Evaluation, and Treatment of High Blood Cholesterol in Adults (Adult Treatment Panel III). Third Report of the National
Cholesterol Education Program (NCEP) Expert Panel on Detection, Evaluation, and Treatment of High Blood Cholesterol in Adults (Adult Treatment Panel III) final report. Circulation. 2002; 106: 3142-421.

9. Scott JA, King GL. Oxidative stress and antioxidant treatment in diabetes. Ann NY Acad Sci. 2004; 1031: 204-13.

10. Jia J, Zhang X, Hu YS, Wu Y, Wang QZ, Li NN, et al. Evaluation of in vivo antioxidant activities of Ganoderma lucidum polysaccharides in STZ-diabetic rats. Food Chem. 2008; 115: 32-6.

11. Li F, Zhang Y, Zhong Z. Antihyperglycemic effect of ganoderma lucidum polysaccharides on streptozotocin-induced diabetic mice. Int J Mol Sci. 2011; 12: 6135-45.

12. Seto SW, Lam TY, Tam HL, Au AL, Chan SW, Wu JH, et al. Novel hypoglycemic effects of Ganoderma lucidum water-extract in obese/diabetic $(+\mathrm{db} /+\mathrm{db})$ mice. Phytomedicine. 2009; 16: 42636.

13. Venegas-Pino DE, Banko N, Khan MI, Shi Y, Werstuck GH. Quantitative analysis and characterization of atherosclerotic lesions in the murine aortic sinus. J Vis Exp. 2013; 82: 50933. doi: 10.3791/50933.

14. Mendizábal Y, Llorens S, Nava E. Hypertension in metabolic syndrome: vascular pathophysiology. Int J Hypertens. 2013; 2013: 230868. doi: 10.1155/2013/230868.

15. Repetto M, Semprine J, Boveris A. Lipid peroxidation: Chemical mechanism, biological implications and analytical determination. In: Catala A, editor. Lipid Peroxidation. Argentina: University of Buenos Aires, School of Pharmacy and Biochemistry, General and Inorganic Chemistry, Institute of Biochemistry and Molecular Medicine (IBIMOL-UBA-CONICET); 2012. p.7-17.

16. Allahverdian S, Pannu PS, Francis GA. Contribution of monocytederived macrophages and smooth muscle cells to arterial foam cell formation. Cardiovasc Res. 2012; 95: 165-72.

17. Song YS, Kim SH, Sa JH, Jin C, Lim CJ, Park EH. Anti-angiogenic and inhibitory activity on inducible nitric oxide production of the mushroom Ganoderma lucidum. J Ethnopharmacol. 2004; 90: 17 20.

18. Chen XP, Chen Y, Li SB, Chen YG, Lan JY, Liu LP. Free radical scavenging of Ganoderma lucidum polysaccharides and its effect on antioxidant enzymes and immunity activities in cervical carcinoma rats. Carbohydr Polym. 2009; 77: 389-93.

19. Meng GL, Zhu HY, Yang SJ, Wu F, Zheng HH, Chen E, et al. Attenuating effects of Ganoderma lucidum polysaccharides on myocardial collagen cross-linking relates to advanced glycation end product and antioxidant enzymes in high-fat-diet and streptozotocininduced diabetic rats. Carbohydr Polym. 2011; 84: 180-85.

20. Fikriah I. Effect of curcumin on the effect on the levels of total cholesterol, LDL-cholesterol, the amount of F2-Isoprostan and foam cell in aortic walls of rats with atherogenic diet. Folia Medica Indonesiana. 2007; 43: 136-40.

21. Sliva D. Ganoderma lucidum (Reishi) in cancer treatment. Integr Cancer Ther. 2003; 2: 358-64. 